University of Nebraska - Lincoln

DigitalCommons@University of Nebraska - Lincoln

December 1989

\title{
Public Pension Power for Socioeconomic Investments
}

F. Gregory Hayden

University of Nebraska-Lincoln, ghayden1@unl.edu

Follow this and additional works at: https://digitalcommons.unl.edu/econfacpub

Part of the Economics Commons

Hayden, F. Gregory, "Public Pension Power for Socioeconomic Investments" (1989). Economics Department Faculty Publications. 11.

https://digitalcommons.unl.edu/econfacpub/11

This Article is brought to you for free and open access by the Economics Department at DigitalCommons@University of Nebraska - Lincoln. It has been accepted for inclusion in Economics Department Faculty Publications by an authorized administrator of DigitalCommons@University of Nebraska - Lincoln. 


\section{Public Pension Power for Socioeconomic Investments}

\section{F. Gregory Hayden}

We are at a turning point in the United States with regard to state and local public pension funds. First there is a movement to use these pension funds to support new kinds of investment activities, and second, the current economic analysis being provided by economists of the neoclassical ideology is inconsistent with the community intent for the pensions. ${ }^{1}$ These pensions were established by the community for what Thorstein Veblen defined as parental purposes, meaning societal activity structured to provide for the common good and the welfare of others [Veblen 1937, pp. 25-38]. Parental institutions function to elevate the broad common welfare above the self-aggrandizment of a few. In contrast, neoclassical analysis is being conducted from the point of individual self-regard and with the assistance of the tools of methodological atomism. This allows those employing neoclassical ideology to assist in the encapsulation [See Bush 1987] of pension knowledge in opposition to the welfare of the community. If the pension funds are to accomplish community intent, it is, therefore, necessary to establish the primary criteria before the policy turn is made in the wrong direction.

Upon Russia's exit from Afghanistan this past winter, a U.S. television reporter inquired of a Russian soldier, who had suffered multiple

The author is Professor of Economics, University of Nebraska-Lincoln and member of the Nebraska Investment Council. He wishes to thank Lynn Moorer for her excellent rescarch and administrative assistance on the Ford Foundation project of which the work found in this article was a part. 
fractures and was severely burned, "What lesson do you think Russia has learned from the Afghan war experience?" His answer was direct, "We must think hard about what we are doing or we will have harsh consequences." That is advice similar to what John Dewey gave us some time ago. However, as the Russians learned, it is not easy to "think hard" if the research intelligence and knowledge creation apparatus is encapsulated by interests inconsistent with the community's best interests. For that reason this author fears that the community may soon suffer harsh consequences with regard to the management and growth of its state and local public pension funds. Neoclassicalists such as Martin Feldstein and James Buchanan have been rewriting the purposes of public pension funds consistent with the criteria of neoclassical ideology. Their work is not consistent with the array of community criteria outlined below.

Thinking hard requires millions of research dollars. If the research resources are squandered on misguided assumptions, incorrect beliefs, and inadequate modeling, the knowledge base thereby put in place will have harsh consequences. The beliefs, models, and conclusions of economists such as Feldstein and Buchanan provide an ideological and encapsulated knowledge base for administrators, asset managers, and policymakers to contort the purposes and uses of the public pension plans. No better example exists of the damage that can be perpetrated through this kind of process than that recently done to our financial structure by John Shad as head of the Security and Exchange Commission (SEC) (more on this below). Shad's policies were consistent with the neoclassical tradition, including a call for neoclassical cost-benefit analysis as justification.

Buchanan and Feldstein were so successful in setting the direction for public pension research during the late 1960s and the 1970s that the policy component of most neoclassical research diverges from community criteria. Miltiadis Nektarios commented on one aspect of this divergence as follows, "it is remarkable that most current proposals for increased funding of public pensions are not based on arguments about the security of future pensions; instead it has been argued that the extra funds should be used to increase current national savings and capital formation" [Nektarios 1982, p. 54]. ${ }^{2}$

Buchanan's own belief criteria included converting public pensions in the direction of the insurance pole [Buchanan and Colin 1966] and removing "the objective of providing all persons with a minimum income as part of an overall welfare program" [Buchanan 1968]. Consistent with the latter criterion, he also believes in the "vesting of 
individualized rights to benefits based on earnings" [Buchanan 1968].

Feldstein believes the individual makes decisions on the basis of utility calculation and that the base of pension analysis should emphasize "the individual's simultaneous decision about retirement and saving" [Feldstein, 1974, p. 95] although he admits "the typical American household might not behave as this theory predicts" [Feldstein 1975]. Feldstein also believes that "to permit everyone to buy as much insurance as he currently gets from Social Security and on the same financial terms, it would be necessary only to offer such insurance on a voluntary basis" [Feldstein 1977]. Methodologically he makes the mistake of believing that efficiency is a concept divorced from criteria [Feldstein 1975 , p. 81]. When he substitutes his own beliefs, his analysis leads him to the conclusion that public pension plans (along with Medicare, Medicaid, the tax subsidy of private insurance, the design of national health insurance, AFDC, food stamps and so forth) need to be drastically redesigned to increase productivity and economic efficiency [Feldstein 1975 , p. 97], as the latter are determined by Feldstein's beliefs. ${ }^{3}$

Of course empirical findings in U.S. history do not support the Buchanan and Feldstein beliefs about rationally calculated utility decisions being able to provide for adequate retirement systems. The social sciences rejected the existence of the utility concept at the turn of the century. With the collapse of the concept of utility, the analysis based on it also collapsed. Thus as stated in the Handbook of Social Psychology, the claims of utility calculation "when tested in the crucible of social policy, proved inadequate" [Allport 1985]. This means the community had to develop real world belief criteria for structuring a pension system, and, as we will see later, the collective beliefs developed in the United States are inconsistent with those posited by Buchanan and Feldstein.

This article is a first step toward the development of a social fabric matrix [Hayden 1982] data base for state and local public pension funds. It is a response to Severyn Bruyn who stated that institutional economics "has yet to be related to the emerging field of social investment" [Bruyn 1987, p. 48]. An important component of any social fabric is the social beliefs. Public pension funds were established to fulfill numerous belief criteria and, as a consequence of rapid growth of the funds and their substantial size, new beliefs with regard to the use and investment of the pensions have continued to evolve. The articulation of the primary criteria that flow from the basic social beliefs is the main purpose of this article.

The current concerns regarding public pension plans makes this an 
excellent time to define more explicitly our primary criteria. In the policy arena we are in the process of extending the list of criteria as new social beliefs evolve. New criteria along with traditional criteria are influencing asset allocation plans. The new investment criteria are referred to by numerous names such as "social investments," or "alternative investments," or "program-related investments," or "targeted investments." The terms "program" or "program-related investing" seem most appropriate because of two characteristics that describe these investments. They are programmatic; that is they are targeted to accomplish a program result, and they are geographically confined; that is they are targeted to provide the benefits of the programs within the fund's sponsoring government's political boundaries.

These new investment criteria are bringing to bear pension power to accomplish socioeconomic results. The trustees of the large pension plans are often encouraged, and in some cases legally required, to invest in local or regional economies and in other cases required to invest in certain programs for venture capital, small businesses, local corporations, student loans, linked bank deposits, housing, local government bonds and so forth. Bruyn has written that "social investment alters the traditional reasons for allocating capital. The professional basis for decision making can no longer be rooted solely in the disciplines of economics and finance. ... The rationale for fiduciary decisions now requires social theory supported by empirical research" [Bruyn 1987, p. vii]. The requirement of social criteria to guide investment, which we can expect to see grow into a movement in the 1990 s, is consistent with the institutionalist agenda.

To understand the recent evolution toward program-related investment, it is important to recognize that this kind of evolution is not unique. Holistic system principles are as relevant to pension systems as to other socioeconomic systems. Socioeconomic systems, which continuously differentiate themselves and evolve, are an integration of (1) cultural values, (2) social beliefs, (3) personal attitudes, (4) institutions, (5) technology, and (6) the natural environment. Public pension systems have differentiated themselves to be concerned, in an explicit policy sense, with more of the elements within each component, and with changing those components through investment policy. Systems theory clarifies that the magnitude of the elements makes a difference in the system. Thus, growth in the magnitude of pension funds continues to change relationships among components. In addition, systems in democratic societies are required to deal with more and more system components because democratic systems, through explicit policy, ex- 
pand concern to more and more components and elements. We cannot develop a rigorous approach to policy making-an approach that will stand up to the scrutiny now being given to pension investing-unless we can formulate explicit primary criteria that can replace the implicit and unwarranted assumptions and vague or narrow intentions that often guide policy actions.

\section{Large and Inadequate}

In one sense, the size of public pension funds referred to above should be considered too small because most of them are underfunded in the sense of the flow of future payments necessary to meet the planned retirement benefits of beneficiaries. Because of the underfunding, the argument is often made that the main investment goal of pension funds is to maximize pecuniary return consistent with acceptable risk. Maximum pecuniary return is sought in order to assure an adequate fund at retirement time and to minimize the taxpayers' expense because many of the pension plans are defined benefit plans that must be paid by the government if the pension fund is not adequate at the time of retirement. A small percentage loss in investment return over the years engenders a large percentage increase in taxes. This emphasizes the reason plan beneficiaries and taxpayers are concerned about achieving high rates of return without undue risk.

In another sense, the size of public pension funds is phenomenally high. They are nearing the $\$ 1$ trillion mark now and are expected to reach $\$ 4$ trillion in the 1990 s. Or stated differently, public pension funds are a major source of money in our economy for both investment and speculation. For example, some state funds have been major players in the hostile take-over and LBO game. As the principal investigator on a recent Ford Foundation research project, my advisory committee consisted of investment officers from the largest public pension funds. When we sat down together last December in New York, four of the officers represented a majority of the funding for the Nabisco take-over. Others represented funds that had lost because the triple $\mathrm{A}$ bonds they held had tumbled as a result of that take-over.

\section{Opposition to Program Related Investments}

When discussions on new kinds of investment criteria for pension funds are initiated, an array of arguments is brought forward to defend the status quo in investment policy. Some opposition results from cur- 
rent asset managers not wanting to share the funds with alternative asset managers, and some results from beneficiary groups with political power, such as teachers or police, who see any explicit change in investment policy as an increase in risk. However, much opposition is the ideological opposition of financial experts who have a misguided view that the only consequences that should be considered in making investment decisions are those related to the pecuniary rate of return. The latter view, which is often heeded, is based on at least three misassumptions.

\section{Money and Society}

First it fails to recognize that there is no one set of uses of money, or one set to which money flows are to be directed, that is separate from social policy. The control of pension funds is the control of large sums of money flows. Among different people, and at different points in the history of any people, money has had different uses and consequences. "Modern concepts of money did not exist in primitive cultures. Primitive tribes had a group of objects that served as money depending upon the situation. In these cultures it was possible that one object was used for a means of payment, and another for a standard of value, a third object for a store of value and a fourth object for exchange purposes" [Karl Polanyi, quoted in Eberle 1988]. These four define the extent of the functions of money; however, they do not define the extent of the uses and consequences of money in a social system. Money is a technology and its use, the extent of its use, and changes in its use create social institutions, and therefore it is institutionally specified. There is no natural use or natural evolution of money, so there is no one bottom line or one consequence such as rate of monetary return that should be considered the natural determinant of where money should flow.

The natural or confined use of money argument in social investment policy comes in part from the assumption that money evolved to replace barter for economic efficiency reasons. The assumption "is the common explanation that the use of money arose out of the inconveniences of barter. By itself this explanation is no more adequate than to say that the telephone came because smoke signals from hilltops were a lot of bother" [Ederer 1964, p. 39]. The assumption that money evolved for economic efficiency reasons has been effectively refuted by numerous anthropological studies. Most of the evidence suggests that money and barter have coexisted. In fact there are examples where people with complex economies have decoupled money from their econ- 
omy and moved to barter because money created relationships that these people did not accept socially [Eberle 1988]. Thus the degree of barter as well as the kind and flow of money are issues of social policy. That is quite clear in the United States in view of the vast web of codes, regulations, and policies regarding money and financial institutions, along with the development of special monies such as letters of credit and food stamps. With changes in the kind and use of money, society changes. "Money as soon as it is used for any purpose generates its own distinctive institutions" [Crump 1981, p. 1]. Changing pension investment flows with the intent to change society is consistent with the monetary history of many different peoples, including those of the United States.

\section{Money and Power}

The second misassumption is a failure to recognize the relationship between money and power. "One of the prime social functions is the political control of the supply of investment. The political system encourages and gives rights to pursue investment and sanctions the resulting power. Interest controls the release of funds and gives rights to intervene" [Parsons 1960, p. 75]. Therefore whether in "private" financial institutions or government ones, rules guiding property rights and investment prescribe power. The establishment of preferred power relationships such as democracy cannot be achieved without concomitant investment policies. By condoning any set of investment policies, pension officers and trustees are condoning a particular set of power relationships. For example, the use of public pension funds in the 1980s to assist in hostile take-overs, leveraged buyouts, and green mail has helped to concentrate power in particular hands.

\section{Legal Meaning of Fiduciary Responsibtlity}

The third fact that the narrow pecuniary rate of return assumption fails to recognize is the legal meaning of fiduciary responsibility. Fiduciary responsibility calls for social prudence as well as prudent investments. It would not take much thoughtful reflection to recognize that a prudent investor would consider the nonfinancial impact of investment decisions. A review of legal history regarding pension investments demonstrates that conclusion. Scott's Law of Trusts indicated that fiduciary duty calls upon investment offices to not limit their concern to maximization of return and "advocated reliance on moral and 
social considerations in fiduciary investments" [Leibig 1980, p. 12]. Scott's Law of Trust reads:

In making and retaining investments, the question arises whether trustees are rigidly bound to attempt to secure the maximum return, whether as to income or principal, consistent with safety....

Trustees in deciding whether to invest in, or to retain, the securities of a corporation may properly consider the social performance of the corporation. They may decline to invest in, or to retain, the securities of corporations whose activities or some of them are contrary to fundamental and generally accepted ethical principles. They may consider such matters as pollution, race discrimination, fair employment and consumer responsibility....

Of course they may well believe that a corporation which has a proper sense of social obligation is more likely to be successful in the long run than those which are bent on obtaining the maximum amount of profits. But even if this were not so, the investor, though a trustee of funds for others, is entitled to consider the welfare of the community, and refrain from allowing the use of the funds in a manner detrimental to society [Scott 1978, 227.13].

Michael T. Leibig's review of state government statutes regarding trust investments leads him to state that "none of the statutes prevents the consideration of noneconomic criteria in investment decisionmaking or suggests that the duties of care, caution, and investigation do not include mandatory consideration of known relevant, noneconomic. social factors" [Leibig 1980, p. 181.

The Employee Retirement Income Security Act of 1974 (ERISA) is the primary federal law controlling private pension investments, and in addition it serves as a standard regarding fiduciary standards for public pension funds. An examination of the relationship between ERISA and social investment indicates that "the fiduciary who refuses to consider the social impact of an investment when presented with a factual demonstration of the benefit or detriment of the investment to plan participants or beneficiaries, or with plan instruments which require such consideration, may be liable for violation of a legally enforceable duty of social prudence" [Leibig 1980, p. 25].

The Internal Revenue Service has ruled that "low-risk investments that produce income and also serve a social purpose will not be considered a diversion of the corpus or income from the trust's purpose even though such investments yield a rate of return lower than that in the current market" [U.S. Internal Revenue Service 1970].

A full review of the many challenges on issues related to social investing indicates that there exists a legal duty to employ social prudence criteria as part of prudent investment criteria. 


\section{Beliefs, Criteria, Fact and Analysis are Related}

As in any social scientific endeavor, fact cannot be separated from beliefs and values. Dan McGill has emphasized this point in his book, Social lnvesting. He turns to distinguished ethicians and philosophers to find that "the realm of fact can neither be defined nor specified without using certain values, that it is impossible to stand firmly on the fact side of the fact-value distinction, while treating the other as vaporous, and finally, that the same processes which carve facts out of undifferentiated unconceptualized stuff also carve out the values. So it is well to look hard at the moral dimensions of decision making in pension fund uses" [McGill 1984, pp. 3-4]. Thus it is necessary to look behind the facts before creating them. Thorstein Veblen was an early proponent of binding analysis and data collection to belief criteria. He wrote in the Theory of the Leisure Class that

the ground on which a discrimination between facts is habitually made changes as the interest from which the facts are habitually viewed changes. $\ldots$ The habit of distinguishing and classifying the various purposes and directions of activity prevails of necessity always and everywhere; for it is indispensable in reaching a working theory or scheme of life. The particular point of view, or the particular characteristic that is pitched upon as definitive in the classification of the facts of life depends upon the interest from which a discrimination of the facts is sought [Veblen 1934, $p$. 9].

He also laid out a set of concerns or social beliefs to which his analysis and empirical evidence were devoted. For example, his analysis was used to evaluate how well a community measured up in being parental and committed to workmanship. Figure 1 is intended to outline a policy approach consistent with Veblen.

\section{Public Policy Model}

Figure 1 indicates, starting on the left of the figure, that social beliefs, values, and ethical standards are prerequisites for determining social goals and establishing primary criteria. Primary criteria are put into operation and monitored through the development of secondary criteria. Secondary criteria are the social and performance indicators or measures. Figure 1 reflects John Dewey's concept of social measurement as a spectrum from qualification to quantification [Dewey 1938, pp. 200-211].

Figure 2 is an application of Figure 1 to public pension plans. In Figure 2 the Social Beliefs section of Figure 1 is divided into two parts: 


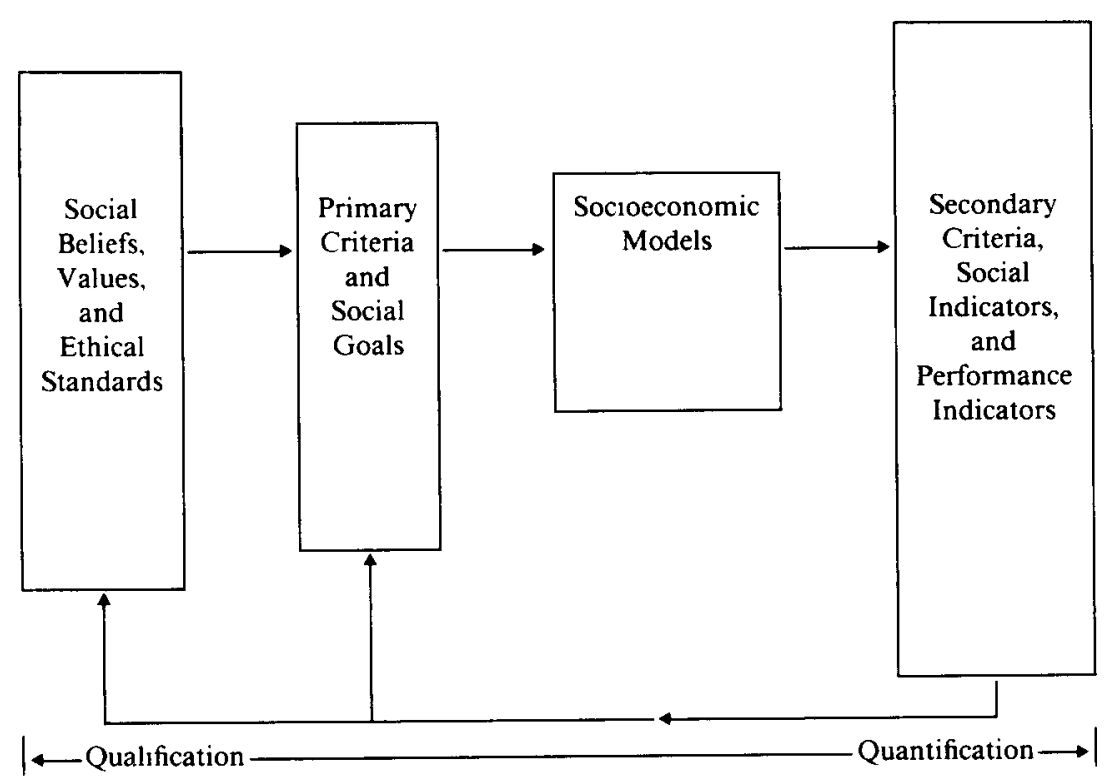

Figure 1. Policy Analysis Paradigm

I. Beliefs and Ethics, and II. Legal Authority. Legal authority concerns have been developed consistent with social beliefs as well as consistent with the primary social criteria. Before we know what is to be accomplished it is necessary to define the primary criteria.

The list of primary criteria, which will be defined below, have been taken from statutes, policy statements, court decisions, rules, regulations, scientific literature, and operational procedures. Generally they are consistent with Veblen's more general criteria of parentalness and workmanship. In Figures 1,2, and 3 it is clarified that secondary criteria cannot be designed except with respect to the context of socioeconomic models of reality.

The secondary criteria-the measures of success-are divided into three categories in Figures 2 and 3. Indicators are needed with regard to Funding Procedures and Plans, Investments, and Retirement Payout Plans. These are already well-developed with regard to the primary criteria and beliefs that have traditionally and explicitly been pursued in 


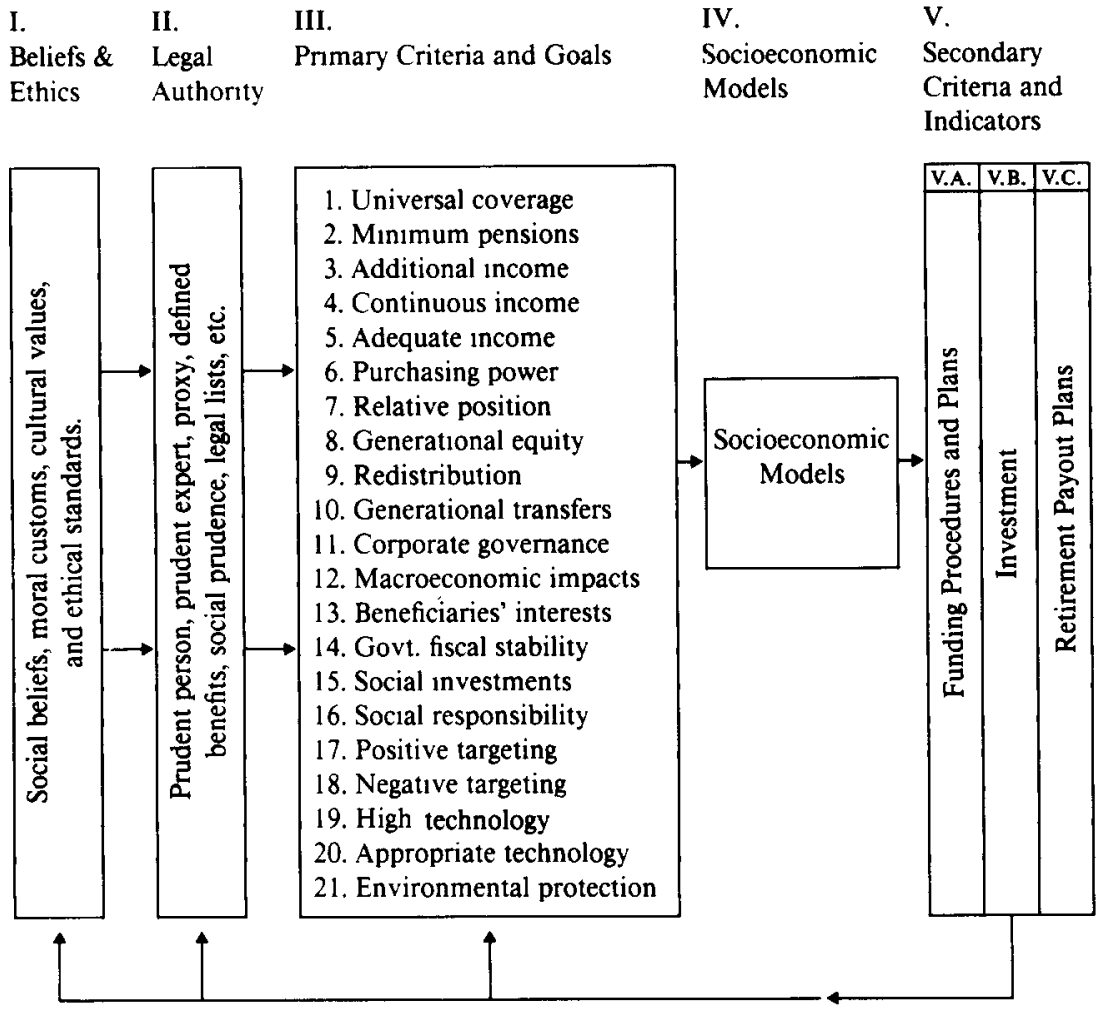

Figure 2. Policy Analysis Paradigm for Public Pension Plans

public pension plans. New ones will have to be developed with the new thrust in program-related investing.

Figure 3 is identical to Figure 2 except that all areas have been shaded except for those defined here as the concerns of social investment. The latter are numbers $12,13,14,15,17$, and 19. There is room for disagreement about what should be included and what excluded. One might wish to include corporate governance since the concern is related to social consequences. However it is not included because direct investment decisions of the corporation are not being controlled by the pension plan. Social responsibility investing is not included because it 


$\begin{array}{lllll}\text { I. } & \text { II. } & \text { III. } & \text { IV. } & \text { V. } \\ \text { Beliefs \& } & \text { Legal } & \text { Primary Criteria and Goals } & \text { Socioeconomic } & \text { Secondary } \\ \text { Ethics } & \text { Authority } & & \text { Models } & \text { Criteria and } \\ & & & & \text { Indicators }\end{array}$

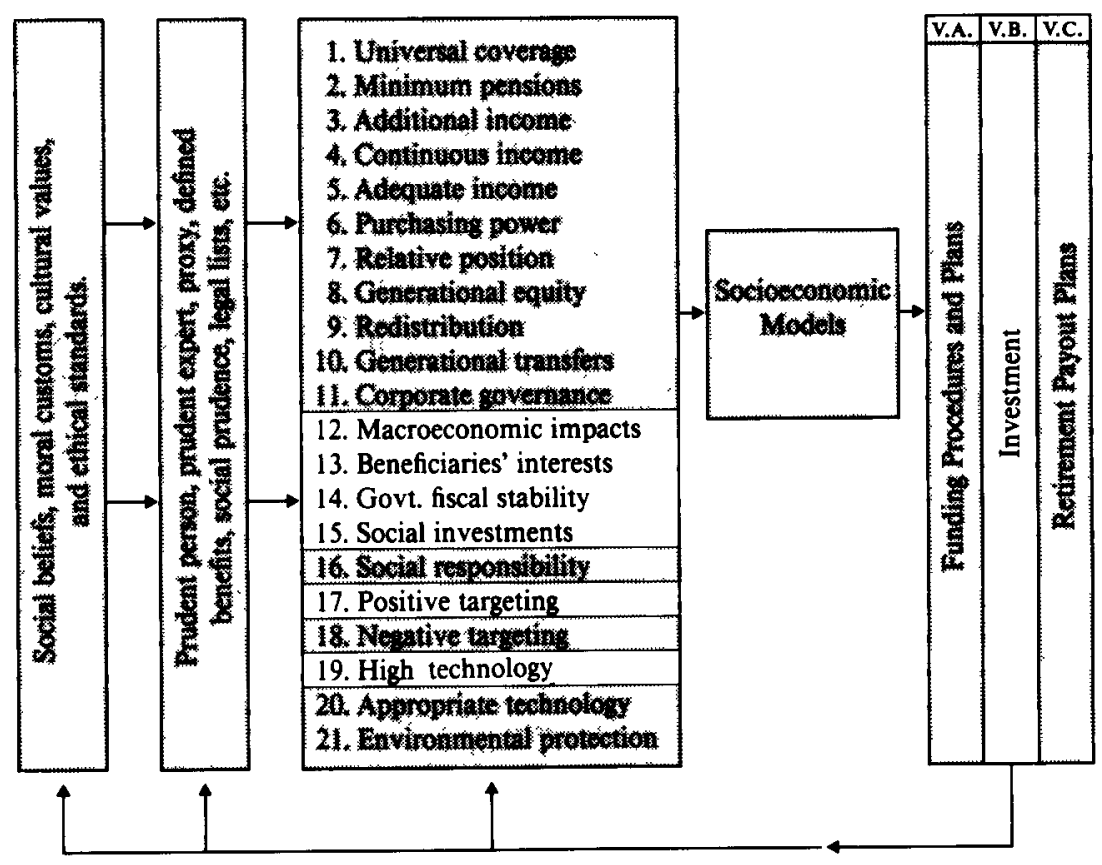

Figure 3. Policy Analysis Paradigm for Public Pension Plans

is a passive concept. The pension officers and investment managers simply withhold investment money from corporations that are not socially responsible.

\section{Primary Criteria}

An anterior question to be addressed is why even have public pension funds? The question arises, why should there be public pension funds at all for government employees? Do not governments have the power to tax so they can tax and pay the beneficiaries at the time of retirement? Why is it necessary to waste resources by using asset man- 
agers, stock brokers, LBO specialists, venture capitalists, bond arbitrators, insurance companies, custodian trustees, consultants, and so forth? Is not a whole array of people being paid handsomely and other resources being used to accomplish an unneeded and wasteful result?

Answers can be found in our political and social system. Without the guarantee of a pension fund, a tax-slashing administration could come to power, especially during an economic downturn, declare a fiscal exigency, and cut the taxes necessary to make payments to retirees. In addition the political clout of beneficiaries is enhanced by adding the clout of those financial interests mentioned above to protect and maintain the pension plan. Socially, beneficiaries have vested rights and claims in the fund provided by contract.

The following primary criteria list is not applicable to all pension funds, and some of those on the list are inconsistent with others on the list. However all are applied to various public pension plans as a whole.

The criteria are:

1. Universal coverage: To provide for universal coverage because as a member of the community an individual has a right to an old-age pension.

2. Minimum pensions: To provide a minimum pension irrespective of work or earning history. Those individuals with inadequate or no work and earning history have a right to a mimimum pension.

3. Additional source of income: To provide additional income to particular employee groups in the form of pension plans instead of wages.

4. Continuity of pension income: To mitigate the uncertainties of pre-retirement and retirement life by the maintenance of a continuous flow of income during retirement.

5. Adequate retirement income: To maintain an adequate retirement income.

6. Purchasing Power. To adjust the pension to a price index in order to maintain real purchasing power after inflation.

7. Maintenance of relative socioeconomic position: To adjust the pension for inflation, productivity, and other changes in order to maintain the relative socioeconomic position of the retired individual.

8. Intragenerational equity: To maintain a pension that bears a certain relationship to pre-retirement earnings for each member in the same generation. 
9. Redistributional impacts: To redistribute income and wealth across income groups.

10. Intergenerational transfers: To redistribute income and wealth across generational groups.

11. Influence of corporate governance: To sponsor shareholder campaigns to influence corporate governance issues (such as, Delaware incorporation, poison pills, confidential voting).

12. Macroeconomic impacts: To influence macroeconomic variables such as savings rates, employment, economic growth, investment, interest rates, or labor markets. This might be referred to as economic development or regional economic impacts. Economic development is one of the many reasons pension funds are currently pursuing program-related investments. For example, many states now have geographically targeted venture capital funds for small business start up and expansion.

13. Beneficiaries' vital interest: To direct pension investments so they do not impair the vital economic and social interests of the fund beneficiaries. Beneficiaries' vital interests are a concept similar to that of macroeconomic impacts. The difference is that the impacted party is more narrowly defined and the consequences of concern are more broadly defined. The party is limited to beneficiaries - not the broader community - and the list of concerns goes beyond economic impacts to include health, wage scale, labor relations, pollution, and so forth.

14. Governmental financial stability: To invest in the bonds of governmental units that sponsor the pension. Since the pension plan is dependent on the fiscal health of its sponsoring government, the pension funds are sometimes used to buy government bonds in a time of fiscal crisis. New York City was one of the first major cases for this kind of "bailout."

15. Social investments: To direct investment expenditures in a manner so as to increase production of particular goods and services. Housing has been one of the main recipients of social investment.

16. Social responsibility: To direct investment into organizations whose organization, finance, production, and marketing are conducted in a manner consistent with accepted community and ethical standards, or to encourage the management of organizations in which funds are invested in a socially responsible manner. Corporate investments in South Africa is a prime example. Corporations that invest in South Africa are considered to be supporting apartheid. In Massachusetts an investment boycott 
is in effect with regard to corporations operating in Northern Ireland. However, there are now numerous social responsibility criteria, as was indicated above in the section on the legal meaning of fiduciary responsibility.

17. Positive geographical targeting: To direct investment into a particular geographical area, such as the fund's own political jurisdiction, in order to improve the area.

18. Negative geographical targeting: To prevent investment from flowing to certain geographic areas or political jurisdictions in order to change social, financial, economic, racial, or corporate policies in the area (for example, South Africa).

19. High technology development: To achieve advanced technology developments and innovation through investments in research, seed capital, and high technology investments. For example, state pension funds in Ohio have established a seed capital fund to finance research for the development of new technology.

20. Appropriate technology development: To direct funds into plant and equipment investments that meet appropriate technology criteria.

21. Environmental protection: To target investments to protect, conserve, restore, or regenerate the natural environment.

Elsewhere the author [Hayden 1988] and Walter Neale [Neale 1987] have emphasized the importance of social belief criteria in determining how and why activities are carried on and are justified in a social system. We can see the importance of establishing the primary criteria to guide the activities of public pension plans; such criteria must remain on research agendas.

If the basic social criteria are not established, definitively supported, and heeded through the pension process, we can replicate the fiasco incurred in our financial activities because neoclassicalists such as Gregg Jarrell and Charles Cox were in the SEC directing the policy research that promoted the "free market" doctrine and that guided John Shad as director.

John Shad was a Wall Street operative before becoming Reagan's SEC chairman. His general ideology was that of unrestrained free enterprise; thus his policy was one of hands off with regard to Wall Street corporations. He admired Michael Milken and Ivan Boesky, inviting the latter to lunch with him at SEC headquarters. Both were brash wheel-dealers who we now know amassed multimillion dollar incomes through illegal activities in hostile takeovers, use of insider information for stock trading, and price manipulation. 
As hostile takeovers began to threaten more large stable corporations even Shad became concerned, especially as he was urged by former Wall Street friends who had become worried about the expansive debt creation practices that were being allowed to fuel the practices of corporate raiders. In response, Shad gave a speech titled "Leveraging of America" in which he pointed out that companies burdened by takeover debt were not able to invest in real plant, equipment, research, and development; that many of the companies taken over had strong managements rather than weak ones; and that "the more leveraged takeovers and buyouts today, the more bankruptcies tomorrow" [Vise and Coll 1989].

The Reagan administration became concerned that Shad was deviating from accepted "free market" ideology in favor of constraint in response to real world observations. Neoclassical economists, Jarrell and Cox brought to bear their ideology and concomitant techniques to direct Shad. Jarrell was a free-market doctrine champion, consistent with his training at the University of Chicago. Cox, who had held Jarrell's position before being promoted to SEC Commissioner was "surprised" by Shad's speech. Jarrell said that "the administration's view was that Shad was off the reservation. ... I tried to move him [Shad] wherever the administration wanted to go" [Vise and Coll 1989]. Jarrell worked with other economists "to develop studies that would support the administration's position that takeovers-even the Drexel-sponsored hostile takeovers mounted by corporate raiders who had little cash to finance their bids-were good for shareholders, the economy and the country" [Vise and Coll 1989].

Neoclassical cost-benefit analysis was emphasized to require that the benefits (as defined by neoclassical ideology), of regulation be greater than the predicted cost (as defined by neoclassical ideology). As even neoclassical welfare economists have demonstrated, cost-benefit analysis cannot measure the benefits of policy in monetary terms. Thus it is impossible to ever demonstrate that benefits are greater than monetary costs using cost benefit analysis. It is a technique for inhibiting policy changes.

Finally Jarrell helped engineer the appointment of another neoclassical economist as a SEC commissioner. In January 1986, a month after this appointment, "the SEC voted to back down from nearly all the legislative proposals on takeovers it had submitted to Congress" [Vise and Coll 1989].

The tenure of Shad, Jarrell, and Cox at the SEC was a time of rapid growth of: abuses of inside information, rigged corporate takeovers, 
evasion of security and tax laws, high risk junk bonds, hostile takeovers, acquisitions and mergers, corporate debt in relation to equity, illegal stock trading, manipulation of stock prices, and speculative instruments such as stock index futures. ${ }^{4}$

At SEC the neoclassicalists won an ideological battle based on inappropriate primary criteria, and the nation lost. The same can happen with our public pensions. Pension analysts, asset managers, and administrators can deceive and damage the community at large if community criteria does not guide analysis, investment, and administration.

\section{Notes}

1. Other important current pension issues not covered in this article are the decreasing number of workers who have pension plans and the shift away from defined benefit pension plans [Employee Benefit Research Institute 1989]. In addition a Munkirs-type analysis of who controls the investment of public pension funds is yet to be completed. A casual glance at the recent Pension and Investment Age listing of the leading pension asset managers (Pension and Investment Age, 22 May 1989) leads this author to hypothesize that pension investments are predominately controlled by the Central Planning Core described by John Munkirs [Munkirs 1985].

2. Institutionalists are of course aware of the fallacy of the saving-cum-capital formation-cum-economic growth argument. For an excellent review of the fallacy, see Baldwin Ranson's article [Ranson 1987].

3. For a criticism of Feldstein's analysis, which is based on the life cycle consumption hypothesis, see Miltiadis Nektarios's book [Nektarios 1982].

4. For an analysis of the mergers and acquisitions of the 1980s, see Richard DuBoff and Edward Herman's article [DuBoff and Herman 1989].

\section{References}

Allport, Gordon W. 1985. "The Historical Background of Social Psychology." In Handbook of Social Psychology, Volume I: Theory and Method. Ed. Gardner Lindzey and Elliot Aronson, pp. 1-46. New York: Randon House.

Bruyn, Severyn T. 1987. The Field of Social Investment. Cambridge: Cambridge University Press.

Buchanan, James M. 1968. "Social Insurance in a Growing Economy: A Proposal for Radical Reform." National Tax Journal 21 (December): 386-95.

Buchanan, James M. and Colin D. Campbell. 1966. "Voluntary Social Security." Wall Street Journal, 20 December, p. 10.

Bush, Paul D. 1987. "The Theory of Institutional Change." Journal of Economic Issues 21 (September): 1075-1116. 
Crump, Thomas. 1981. The Phenomenon of Money. Boston: Rutledge \& Kegan.

Dewey, John. 1938. Logic: The Theory of Inquiry. New York. Henry Holt and Company.

DuBoff, Richard B. and Edward S. Herman. 1989. Journal of Economic Issues 23 (March): 107-33.

Eberle, David. 1988. "Money Talks: The Language of Money." Unpublished Term Research Paper, University of Nebraska, Lincoln, Nebraska.

Ederer, Rupert J. 1964. The Evolution of Money. Washington D.C.: Public Affairs Press.

Employee Benefit Research Institute. 1989. What is the Future for Defined Benefit Pension Plans? Washington, D.C.: Employee Benefit Research Institute.

Feldstein, Martin. 1974. "Social Security, Induced Retirement, and Aggregate Capital Accumulation." Journal of Political Economy 82 (September/October): $905-26$. 1975. "Toward a Reform of Social Security." The Public Interest 40 (Summer): 75-95.

1976. "Social Security and Saving: The Extended Life Cycle Theory." American Economic Review: Papers and Proceedings 66 (May): 77-86.

1977. "Social Insurance." In Income Redistribution. Ed. Colin D. Campbell. Washington D.C.: American Enterprise Institute.

Hayden, F. Gregory. 1982. "Social Fabric Matrix: From Perspective to Analytical Tool." Journal of Economic Issues 16 (September): 637-61.

1983. Investment of Nebraska Public Pension Funds: Report of Governor Robert Kerrey's Task Force on State Public Pension Fund Investment. Lincoln: Office of Governor.

1988. "Values, Beliefs, and Attitudes in a Sociotechnical Setting." Journal of Economic Issues 22 (June): 415-26.

Hayden, F. Gregory, Douglas C. Kruse, and Steve C. Williamson. 1985. "Industrial Policy at the State Level in the United States." Journal of Economic Issues 19 (June): 383-96.

IMF Survey. 1988. "Selected Topics: Benefits of International Debt Facility are Examined in September Staff Papers." IMF Survey (October 31): 341-44.

Ippolito, Richard A. 1986. Pensions, Economics and Public Policy. Homewood: Dow-Jones-Irwin.

Lanoff, Ian D. 1980. "The Social Investment of Private Pension Plan Assets: May It Be Done Lawfully under ERISA?" Labor Law Journal 31 (July): 387-92.

Leibig, Michael T. 1980. Social Investments and the Law. Washington D.C.: Conference of Alternative State and Local Policies.

Litvak, Lawrence. 1981. Pension Funds \& Economic Renewal. Washington D.C.: The Council of State Planning Agencies.

McGill, Dan M. Ed. 1984. Social Investing. Homewood: Richard D. Irwin, Inc.

Munkirs, John R. 1985. The Transformation of American Capitalism: From Competitive Market Structures to Centralized Private Sector Planning. New York: M.E. Sharpe, Inc.

Neale, Walter C. 1987. "Institutions." Journal of Economic Issues 21 (September): $1177-1206$.

Nektarios, Miltiadis. 1982. Public Penstons, Capttal Formation and Economic Growth. Boulder: Westview Press. 
Parsons, Talcott, 1960. Structure and Process in Modern Societies. New York: The Free Press.

Pensions \& Investment Age. 1989. "Directory: Managers Ranked by TaxExempt Assets." Pensions \& Investment Age (May 22): 3-8.

Ranson, Baldwin. 1987. "The Institutional Theory of Capital Formation." Journal of Economic Issues 21 (September): 1265-80.

Schwimer, Martin J. and Edward Malca. 1976. Pension and Institutional Portfolio Management. New York: Praeger Publishers.

Scott, Austin W. 1978 [Supplement]. The Law of Trusts. Vol. III. 227-13. Boston: Little, Brown.

Smith, Adam. 1937. The Wealth of Nations. New York: The Modern Library.

Stoeber, Edward A. 1976. Pension Reform Act Explained: New Guidelines for Corporate, Keogh, and Individual Retirement Plans. Cincinnati: The National Underwriter Company.

U.S. Internal Revenue Service. 1970. Revenue Ruling 70-536, 1970-2 C.B. 120.

Veblen, Thorstein. 1934. The Theory of the Leisure Class: An Economic Study of Institutions. New York: The Modern Library.

1937. The Instinct of Workmanship and the State of the Industrial Arts. New York: The Viking Press.

Vise, David A. and Steve Coll. 1989. "Takeover Mania and the SEC." The Washington Post National Weekly 6 (March 6-12): 12-13.

Winklevoss, Howard E., Dan M. McGill, Glenn D. Allison and Roy S. Neff. 1979. Public Pension Plans: Standards of Design, Funding, and Reporting. Homewood: Dow-Jones-Irwin.

Wokutch, Richard E., Kent F. Murrmann and Jeffrey D. Schaffer. 1984. "Targeted Investing: A Study of Policies and Practices of State Public Employee Pension Funds." In Research in Corporate Social Performance and Policy. Ed. Lee E. Preston. London: JAI Press, Inc. 